\title{
Change in the Vertical Relation in Class II Deformity with Skeletal Open Bite in the Orthognathic Surgery
}

\author{
Nezar Watted ${ }^{1, *}$, Obaida Awadi ${ }^{2}$, Josip Bill ${ }^{3}$, Peter Proff ${ }^{4}$, Muhamad Abu-Hussein ${ }^{5}$ \\ ${ }^{1}$ Arab American University, Jenin, Palestine \\ ${ }^{2}$ Center for Dentistry, Research and Aesthetics, Jatt, Israel \\ ${ }^{3}$ Clinic for Cranio-maxillo-facial surgery Würzburg, Germany \\ ${ }^{4}$ Department of Orthodontics, University of Regensburg, Germany \\ ${ }^{5}$ Department of Pediatric Dentistry, University of Athens, Greece
}

Copyright (C) 2015 Horizon Research Publishing All rights reserved.

\begin{abstract}
The continuously growing esthetic awareness for the facial appearance and the spreading of information about the possibilities of adult treatment by public media result in an increase of adult patients seek orthodontic treatment to improve their facial esthetics. In general, these patients show such a severe skeletal deformity that it is detectable even by non-experts because of its extraoral manifestation, which is the main motivation for treatment. Because of the nature of these deformities and because of the lacking growth usable for therapy the only promising treatment for these patients is the combined orthodontic-surgical approach. Besides a stable and functional occlusion with physiologic position of the condyle, the goals of treatment are the improvement of the dental and, above all, facial esthetics since the patient judges the success of treatment mostly by the extraoral appearance. The dentofacial appearance must be defined prior to treatment to plan the individual right approach in knowledge of the different treatment possibilities for Angle Class II deformities and thus be able to reach both sides - patient and orthodontist- satisfying result. With this article a systematic therapy concept to treat patients with Class II deformities and skeletal open bite with a long lower face (long face syndrome).
\end{abstract}

Keywords Cephalometrics, Orthognathic Surgery, Impaction of the Maxilla, Autorotation of the Mandible, Positioning of the Condyles, Facial Esthetics

\section{Introduction}

Pre-surgical orthodontic preparation was uncommon for patients requiring orthognathic surgery until the 1960's. However, as surgical techniques advanced and the number of patients choosing an orthognathic approach increased, the patients' and clinicians' desire for optimal esthetic and occlusal results led to the most common current treatment approach. This approach involves pre-surgical orthodontic decompensation of the occlusal relationships and attainment of normal dental alignment. As most orthognathic treatment is planned now, there are two phases of orthodontic tooth movement, namely before and after orthognathic surgery. The disadvantages of having orthodontic interventions both before and after orthognathic surgery include a long treatment time and temporary worsening of facial appearance. Many patients become discouraged. [1,2,3]

Ever since the first orthognathic surgery procedure was performed by Hullihen in 1848, many new techniques and methods have been introduced. The introduction of orthognathic surgery widened the possibilities for treatment of severe malocclusions which could not be treated by orthodontics alone. As shown by Kondo and her colleagues, the limits of orthodontic treatment alone for severe malocclusions are broadening, but the underlying skeletal imbalances remain. Until the 1960 's, orthognathic surgeries were usually performed without any pre-surgical orthodontic treatment. In fact, when Hullihen performed the first mandibular sub-apical osteotomy on a burn victim, he was able to correct the prognathism but created an edge-to-edge occlusion anteriorly [ 29]

The three stage philosophy of orthognathic surgery was later adapted and is still valid today in the majority of cases. These stages involve pre-orthognathic orthodontic treatment to relieve the dental compensations followed by the orthognathic surgical procedure and finally post-surgical orthodontics to finish the case and settle the occlusion.

\section{History and Initial Examination}

The 21-year-old female patient reported first to the prosthodontic department for the replacement of lost lower anteriors because of an accident 6 months prior to the first consultation. Lower left canine and incisors were missing and there was an extensive loss of alveolar bone in this 
region. In addition to the total luxation there were crown fractures in the fourth quadrant. The patient also complained about pain of the temporomandibular joints when chewing which initiated before the accident and she felt an esthetic impairment because of rotated and crowded upper incisors.

The functional analysis showed that because of the impeded lip closure the mandible is habitually protruded to make mouthclosure possible. Thus the condyles were displaced out of their physiologic position ventral and caudal towards the articular eminence. .[31 ]

There was a corresponding functional anterior shift of the mandible from centric relation to maximum intercuspidation (habitual occlusion).

\section{Diagnosis}

The diagnostic records were taken in habitual occlusion as well as in centric relation (Fig. 1a, b, Fig. 2 a-e, Fig. 4). For diagnosis and treatment planning the records with centric relation were taken.

Not only for diagnostic (centric relation) but also for therapeutic (TMD-symptoms) reasons a flat plane splint was inserted for 5 weeks which led to an improvement of the symptoms. In addition, the whole extent of the anterolateral functional shift (forced bite) was evident, the mandible was much more dorsal and deviated to the right so that there was a nonocclusion on the left side.

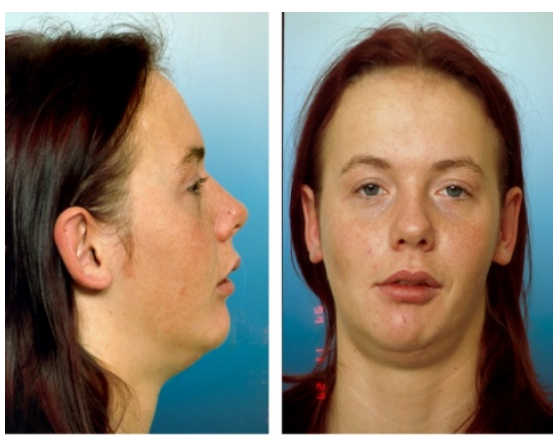

Figure 1a

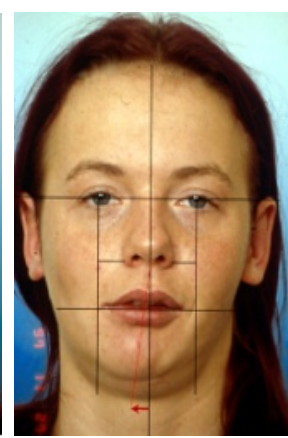

Figure $1 \mathrm{~b}$

Figure 1a, b. Facial and lateral views in centric relation after insertion of the flat plane splint and prior to orthodontic treatment. A pronounced deviation of the mandible to the right -laterognathic- and an aggravated lip closure can be seen (b).

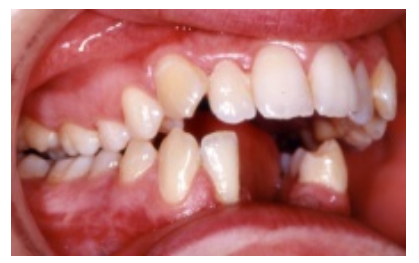

a

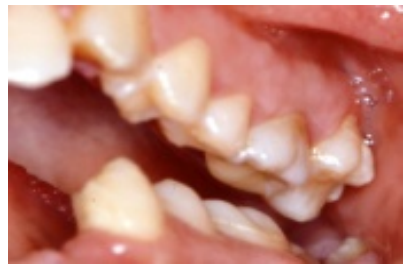

c
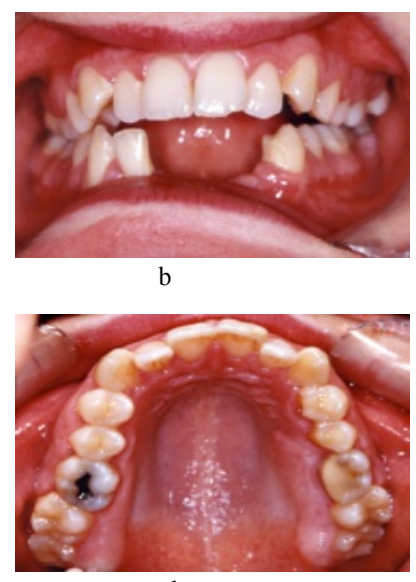

d

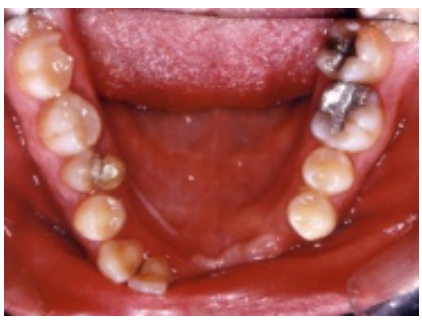

Figure 2a-e. Intraoral views in centric relation: distal occlusion on the right and left side $(\mathrm{a}, \mathrm{b})$. Non-occlusion on the left side (c), crowding in the upper jaw (d) and a reduced number of teeth in the lower jaw with fractures of the lower right second premolar and second molar (e).

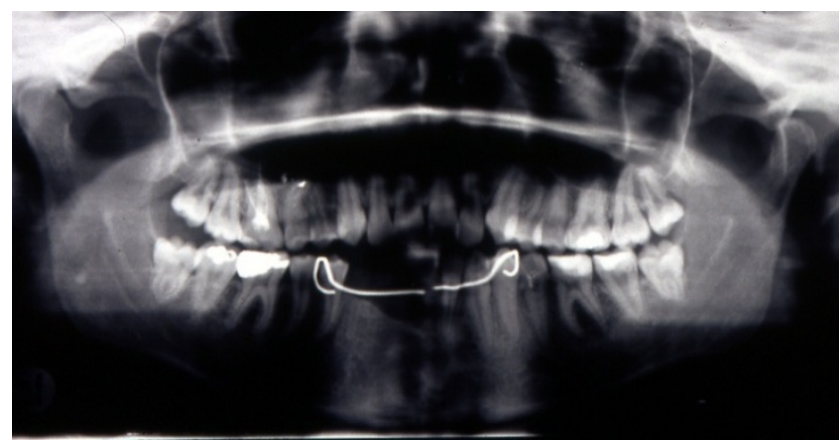

Figure 3. Orthopantomogram (OPG) at the beginning of treatment
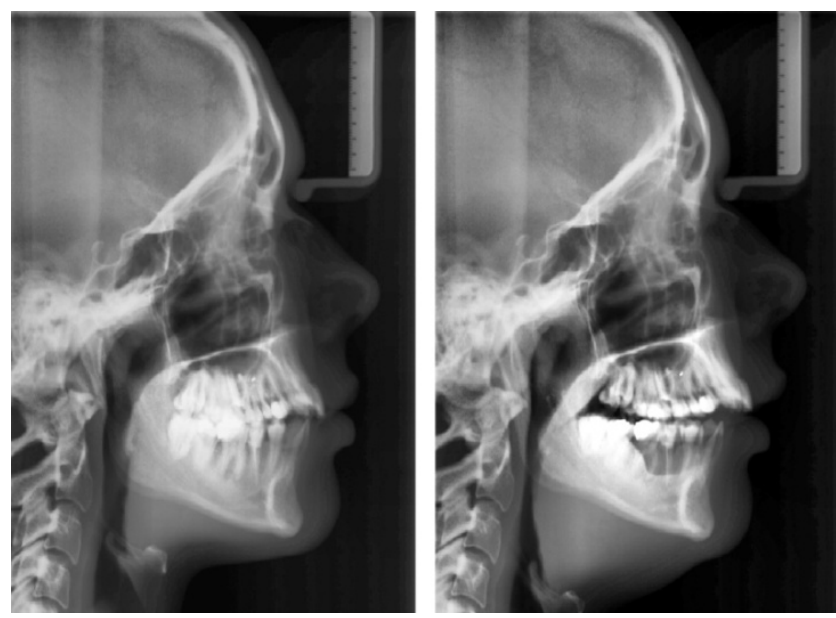

Figure 4. Cephalograms in habitual intercuspidation (left) and centric relation after insertion of a splint (right).

The facial photographs show insufficient mouth- and lipclosure in the centric relation and the described deviation of the mandible to the right. The lateral facial picture shows a posterior divergent face with protruded lip prominence and compared to the mid-face a long lower face $-57 \%$ : $43 \%$ instead of 50\%:50\% (Fig. 2) .[ 33, 34 ]. The Patient had a class II deformity with a mandibular midline shift to the right, a circular open bite and nonocclusion on the left side(Fig. 2a-d). In the upper jaw an arch length discrepancy of $5 \mathrm{~mm}$ existed. The lower jaw showed the reduced number of teeth and the fractures of the lower right second premolar and second molar as consequence of the accident.

The orthopantomogramm (Fig. 4)shows the bone loss in the lower front due to the avulsion of the teeth and the wire 
for the temporary prosthodontic replacement of the lost teeth. Lower right second premolar showed a deep complicated fracture; clinically a grade III mobility was apparent because of the loss of the lingual bone and thus had to be extracted. In addition to the crownfracture of the lower right first molar had an apical lesion. All third molars were erupted and in the lower arch partially covered with gingiva. The most hurting right condyle showed an uneven dent ventral, the left condyle a deformation. The greater abnormality of the right condyle might be caused by the medioventral forced bite.

Cephalometric analysis in centric relation elucidates a vertical and sagittal skeletal as well as soft tissue deformity. The values indicated a skeletal open bite with mild extraoral manifestations of a long face syndrome: Distobasal jaw relation, increased interbase angle $\left(\mathrm{ML}-\mathrm{NL}=33^{\circ}\right.$ ) because of the posterior rotation of the mandible $\left(\mathrm{ML}-\mathrm{NSL}=39^{\circ}\right)$ and anterior rotation of the upper jaw (NL-NSL $=6^{\circ}$ ), slightly reduced ratio of upper to lower facial height $(\mathrm{PFH} / \mathrm{PFH}=$ $60 \%$ ) while growth had been balanced. Because of the loss of lower teeth the dental analysis was reduced to the upper jaw. The vertical distribution of the soft tissue profile showed a disharmony of upper to lower face $\left(\mathrm{G}^{\prime}-\mathrm{SN}: \mathrm{Sn}-\mathrm{Me}^{\prime}=\right.$ 43\%:57\%). This could also be seen in the bony structures (N-Sna : Sna-Me $=40 \%: 60 \%)$. There was also a disharmony in the lower face (Sn-Stms-Me' $=30 \%: 70 \%) \cdot[8,9,34,48$, $49,50]$.

These changes in the ratio were not because of an alteration of the upper lip but more because of a lengthened lower face (, Table 1).

\section{Treatment Plan and Goals}

- Stable and functional Class I occlusion with physiologic position of the condyles

- Optimization of facial esthetics

- Physiologic mouth- and lipclosure

- Optimization of dental esthetics with consideration of periodontal health

- Fulfill the expectation and gain satisfaction of the patient

- $\quad$ Stabilize the result

Besides the stated treatment goals it was the special aim to improve facial esthetics not only in the sagittal but also in the vertical dimension. This was to be obtained by relatively shortening the lower face. Shortening of the lower face as causal therapy with corresponding effects on facial esthetics and lip function could be established only with a combined orthodontic-surgical approach [ 37,48 ]. By solely orthodontic measures the pursued aims concerning esthetics and function could not have been reached. The deformity was too severe for a dentoalveolar compensation. Thus a bimaxillary osteotomy was planned for surgery. To improve the vertical dimension an impaction of the maxilla was necessary which should be greater dorsal than ventral. As consequence of the impaction the mandible with the condyles as "centers of rotation" .[ 43 ] was supposed to autorotate sagittal and vertical; thus a displacement ventral and at the same time cranial of the pogonion was to be expected (Fig. 5 a, b) .[ 21, 22, 23, 26, 45, 51 ].For total correction of the sagittal deformity a surgical advancement of the mandible was planned because the autorotation of the mandible was regarded as nonsufficient for the correction of the distal occlusion.

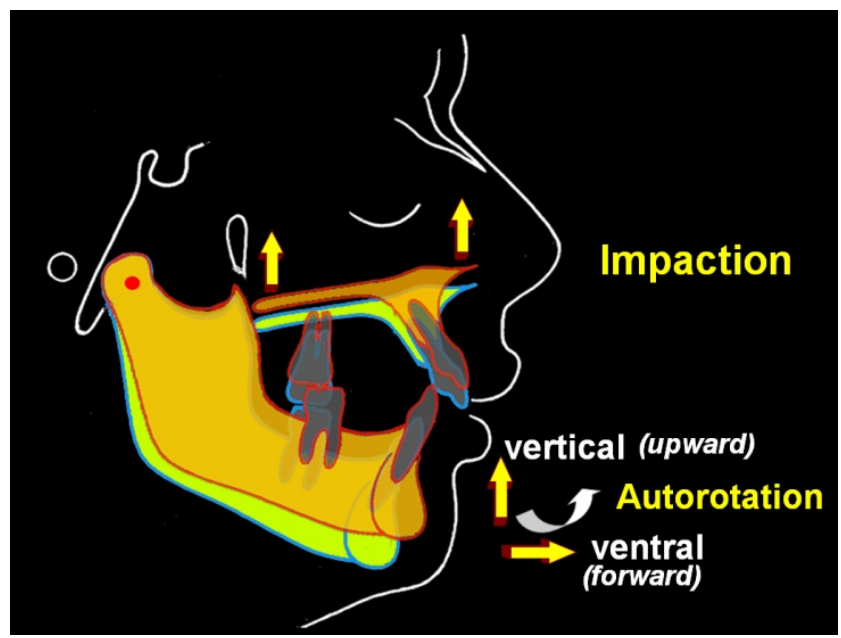

Figure 5a

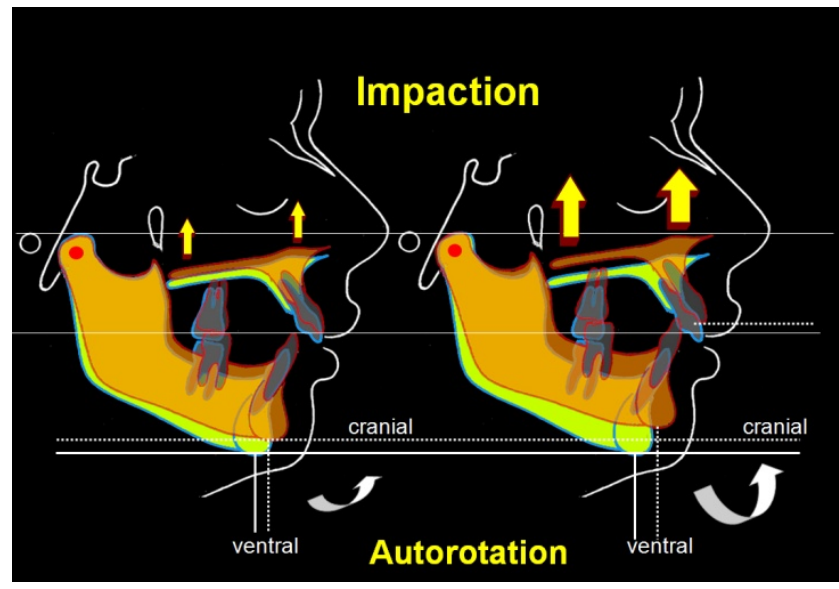

Figure 5b

Figure 5. a: Simulation of the surgical impaction of the maxilla and the reaction of the mandible as described with cranial and simultaneous ventral autorotation.,b: The autorotation and alteration of the Mndibulaposition varies with the amount of impaction of the maxilla

\section{Treatment}

The case was treated according to the Würzburg treatment concept for orthognathic correction of a skeletal deformity and consisted of 4 phases .[ $48,49,50]$ :

\section{I) Presurgery Measures and Orthodontic Setup}

1) "Splint therapy": A flat plane splint was inserted for 5 weeks to establish a physiologic centric relation of the condyles for final treatment planning and to reduce the 
temporomandibular joint pain. Thus the forced bite could be diagnosed to its whole extent.[ 10,11 ]. Diagnostic records with the wrong position of the condyles (because of the forced bite) would have led to a wrong diagnosis, treatment planning and not at last to a treatment with corresponding consequences for the result .[ 52, 53 ]

2) Orthodontic Preparation: The aim of orthodontic preparation was to develop the dental arches, to harmonize them in the three dimensions of space and to eliminate the dental compensation of the skeletal deformity. Decisive for the preparation was the protrusion and torquing of the upper anterioirs not only to eliminate crowding but also with regard to the following surgery whereby the maxilla is impacted and rotated posteriorly. This procedure results in a more retruded position of the anteriors which must be taken into account in the preparation. Thus the presurgical labial inclination could be tolerated. For orthodontic preparation a multibracket appliance ( 0.022 bracket slot) was used. In the upper arch the first arch wire was a $0.014 \mathrm{NiTi}$. The missing teeth in the lower jaw were replaced with artificial teeth which were ligated to a $0.016 \mathrm{x} 0.022$ inch thermoelastic archwire. Further arch wires were a 0.018 inch NiTi in the upper arch and $0.018 \times 0.025$ in NiTi followed by a $0.019 \times 0.025$ in steel in both jaws. The presurgery orthodontic phase lasted 7 months.

3) "Splint therapy" to establish the centric relation 3-4 weeks prior to surgery. Aim of this procedure is to register a physiologic position of the condyle (centric relation) .[52, 53 ]. An inaccurate position of the mandible results in an incorrect planning of the amount of advancement and with that in an inevitable relapse.

II) Surgeryto Correct the Skeletal Deformity

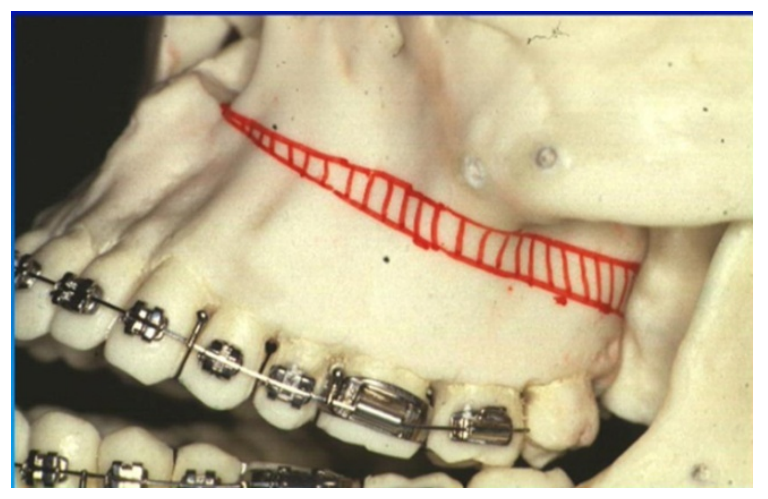

$6 a$

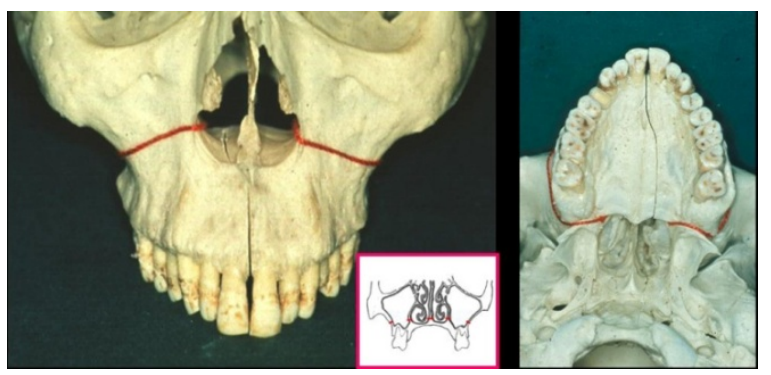

$6 \mathrm{~b}$

Figure 6. LeFort-1 osteotomy of the maxilla

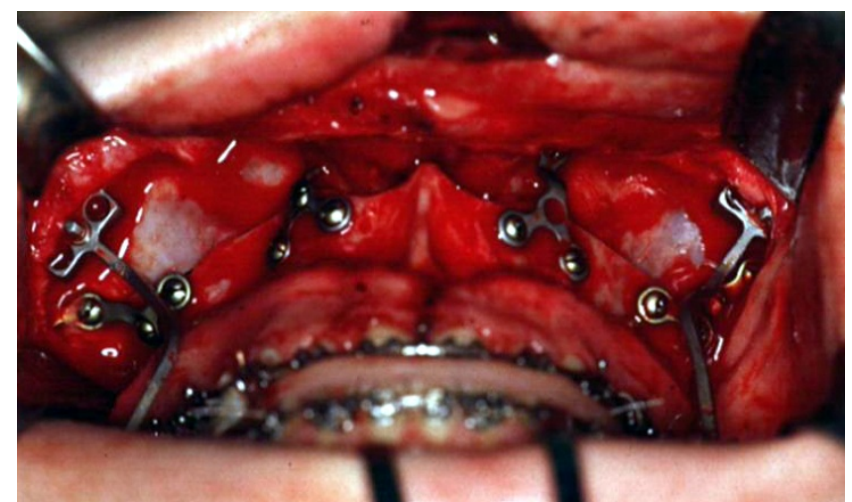

Figure 7. Fixation of the proximal condyle bearing segment in centric position during surgery to keep three dimensional control of the condyles

After surgery on the casts, determining the amount of advancement and fabrication of the splints according to the system used in Würzburg (Four-splint-system: beginning splint or registering splint, maxilla impaction splint, mandible autorotation splint, finishing splint) [ $37,38,47]$. a LeFort-1 osteotomy of the maxilla was performed where the maxilla was impacted cranial: $4 \mathrm{~mm}$ dorsal and $2 \mathrm{~mm}$ ventral so that a posterior rotation of the whole maxilla resulted. With the autorotation of the mandible part of the sagittal deformity could be corrected. The rest of the correction was achieved by a bilateral sagittal split osteotomy of the ramus according to Obwegeser-Dal Pont.[ 15, 16, 39, 40, 41 ]. The surgical advancement was $6 \mathrm{~mm}$ on the right and $2 \mathrm{~mm}$ on the left side with a side shift of $4.5 \mathrm{~mm}$ to the left (Fig. $6 \mathrm{a}, \mathrm{b}$ ). Fixation of the proximal condyle bearing segment in centric position during surgery is a standardised procedure in our Treatment Strategy to keep three dimensional control of the condyles [ 35, 36, 46, 47 ] (Fig. 7)

\section{III) Postsurgery Orthodontics for Finishing}

The earliest possible application of orthodontic forces after surgery is crucial to their impact. muscular forces are eliminated which otherwise would counteract tooth movements.

Thus on the $4^{\text {th }}$ day after surgery postsurgery orthodontics were initiated [ 48, 49 ] with insertion of up and down elastics and for orientation of the muscles to the new position of the mandible light Class II elastics. This phase lastet 3 months.

\section{IV) Retention}

Unwanted side effect from a mandibular advancement is the readjustment and reorientation of the affected soft-tissue and muscles and with that their force against the new position of the mandible. An advancement with transitional movement of the mandible results in stretching and strain of soft tissue and the suprahyoid complex. This tension must be regarded as relapse promoting [ 12, 19, 20, 24, 48, 49 ]. Because the amount of advancement was high and the patient had tense and short muscles of the suprahyoid complex a physiotherapeutic treatment was prescribed to support the rehabilitation and reorientation of the muscles to 
their new position. To support the muscles in their adaptation to the new situation a bimaxillary appliance is suggested for retention- e.g. a bionator. A bionator was fabricated and inserted on the day of debanding. In addition a suck-down splint with artificial teeth to replace the lost incisors was inserted.

2,5 months after completion of orthodontic treatment prosthodontics were initiated. The patient received fixed restorations from lower left scond premolar to the right canine, two blocked crowns for the lower right first and second molar and an appendix to that block for replacement of the right second premolar.

\section{V) Result and Discussion}

The introral pictures show the final situation after prosthodontic rehabilitation (Fig. 8a-d). Class-I occlusion on both sides and harmonising arches could be achieved. The extraoral pictures show a harmonic division of the face in the vertical dimension which was accomplished by shortening the lower face with surgery and a harmonic profile in the sagittal dimension. Profile of the mouth and lipclosure is physiologic (Fig. 9a, b).

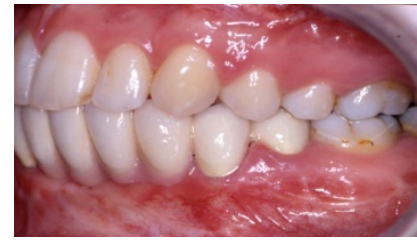

a

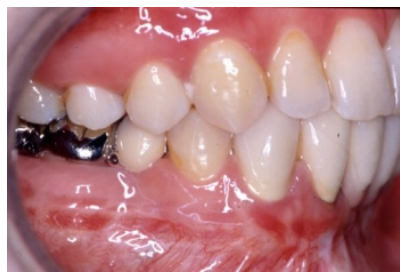

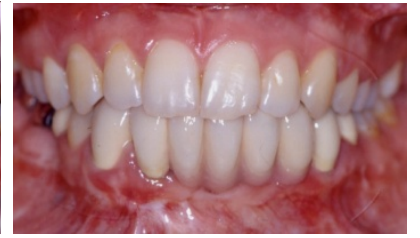

b

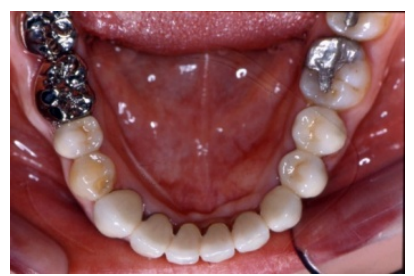

d
Figure 8. a-d: Intraoral views after prosthodontics
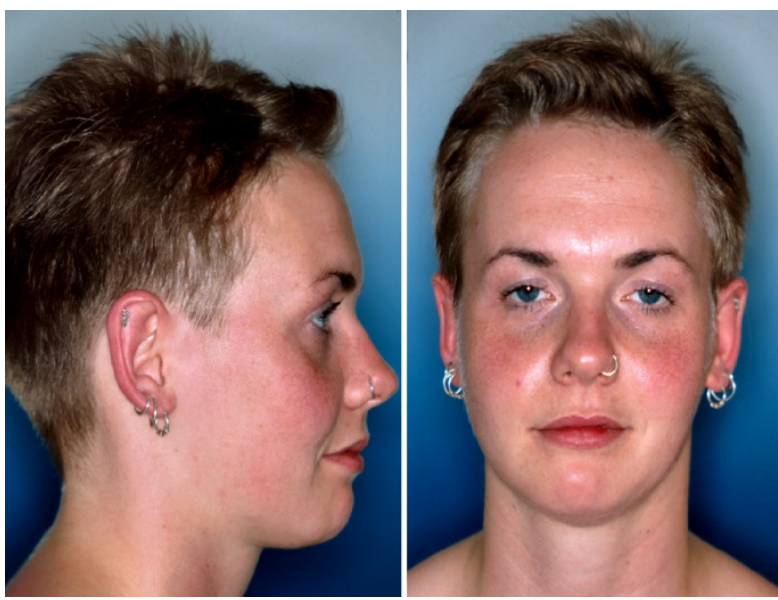

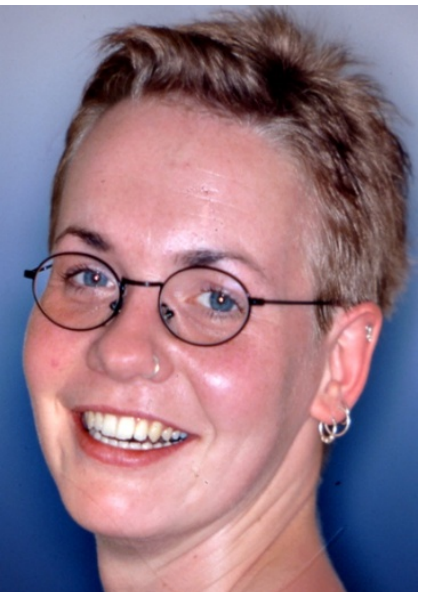

$9 \mathrm{~b}$

Figure 9a, b. Extraoral views after treatment; natural mouth closure and attractive facial appearance

A physiologic distance between maximum intercuspidation and centric relation could be recorded with manual functional analysis. There was no more pain of the temporomandibular joint.

Table 1. Cephalometric analysis Proportions of the soft tissue before and after treatment

\begin{tabular}{|c|c|c|c|}
\hline Variable & Mean & $\begin{array}{c}\text { Pre treatment } \\
\text { (Centric relation) }\end{array}$ & Post treatment \\
\hline $\mathrm{G}^{\prime}-\mathrm{Sn} / \mathrm{G}^{\prime}-\mathrm{Me}^{\prime}$ & $50 \%$ & $43 \%$ & $48 \%$ \\
\hline $\mathrm{Sn}-\mathrm{Me}^{\prime} / \mathrm{G}^{\prime}-\mathrm{Me}^{\prime}$ & $50 \%$ & $57 \%$ & $52 \%$ \\
\hline $\mathrm{Sn}-\mathrm{Stms}$ & $33 \%$ & $30 \%$ & $33 \%$ \\
\hline $\mathrm{Stms}-\mathrm{Me}$ & $67 \%$ & $70 \%$ & $67 \%$ \\
\hline
\end{tabular}

Skeletal analysis: Average values or proportions of skeletal structures before and after treatment

\begin{tabular}{|c|c|c|c|}
\hline Variable & Mean & $\begin{array}{c}\text { Pre treatment } \\
\text { (Centric relation) }\end{array}$ & Post treatment \\
\hline $\operatorname{SNA}\left({ }^{\circ}\right)$ & $82^{\circ}$ & $78^{\circ}$ & $78,5^{\circ}$ \\
\hline $\operatorname{SNB}\left(^{\circ}\right)$ & $80^{\circ}$ & $70^{\circ}$ & $75^{\circ}$ \\
\hline $\operatorname{ANB}\left({ }^{\circ}\right)$ & $2^{\circ}$ & $8^{\circ}$ & 3,5 \\
\hline WITS-Wert (mm) & $\pm 1 \mathrm{~mm}$ & $4 \mathrm{~mm}$ & $1 \mathrm{~mm}$ \\
\hline Facial-K. & $2 \mathrm{~mm}$ & $7,5 \mathrm{~mm}$ & $2,5 \mathrm{~mm}$ \\
\hline ML-SNL $\left({ }^{\circ}\right)$ & $32^{\circ}$ & $39^{\circ}$ & $36^{\circ}$ \\
\hline NL-SNL $\left(^{\circ}\right)$ & $9^{\circ}$ & $6^{\circ}$ & $8^{\circ}$ \\
\hline ML-NL $\left(^{\circ}\right)$ & $23^{\circ}$ & $33^{\circ}$ & $28^{\circ}$ \\
\hline Gonion- $<\left(^{\circ}\right)$ & $130^{\circ}$ & $121,5^{\circ}$ & $125^{\circ}$ \\
\hline $\mathrm{SN}-\mathrm{Pg}\left(^{\circ}\right)$ & $81^{\circ}$ & $71^{\circ}$ & $76^{\circ}$ \\
\hline $\mathrm{PFH} / \mathrm{AFH}(\%)$ & $63 \%$ & $60 \%$ & 64 \\
\hline N-Sna / N-Me (\%) & $45 \%$ & $40 \%$ & $45 \%$ \\
\hline $\begin{array}{c}\text { Sna-Me / N-Me } \\
(\%)\end{array}$ & $55 \%$ & $60 \%$ & $55 \%$ \\
\hline
\end{tabular}


Dental analysis

\begin{tabular}{|c|c|c|c|}
\hline Variable & Mean & $\begin{array}{c}\text { Pre treatment } \\
\text { Centric relation) }\end{array}$ & Port treatment \\
\hline 1-NL $\left(^{\circ}\right)$ & 70 & 73 & 70,5 \\
\hline 1-NS $\left(^{\circ}\right)$ & 77 & 79,5 & 79 \\
\hline 1-NA mm & 4 & 3,5 & 5,5 \\
\hline 1-NA $\left(^{\circ}\right)$ & 22 & $27^{\circ}$ & $29^{\circ}$ \\
\hline
\end{tabular}

The cephalograms show the change of the variables (Fig. $10 \mathrm{a}, \mathrm{b}$, table 1). Because of the surgical impaction and the posterior rotation of the maxilla the inclination of the maxilla was increased by $2^{\circ}$. With that and the following autorotation of the mandible the interplane angle was reduced by $5^{\circ}$. Impaction and autorotation resulted in a decreased anterior face height, which increased the posterior to anterior face height (PFH:AFH=64\%) and thus harmonised this ratio.
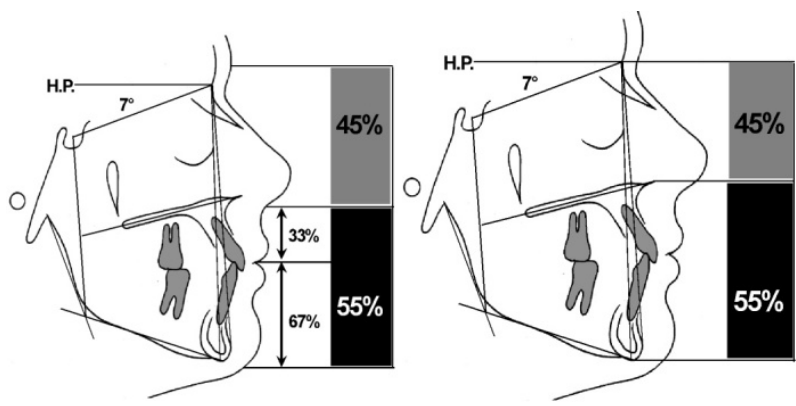

Figure 10 a, b. Cephalogram after treatment; there is a harmonisation of the skeletal (a) and soft tissue (b) structures in the vertical dimension.

The vertical division of the skeletal and soft tissue profile shows a harmonisation. The ratio of skeletal upper to lower face is $45 \%: 55 \%$. The disharmony of the lower third of the face was corrected so that the ratio Sn-Stm : Stm-Me' equals $1: 2(33 \%: 67 \%)$.

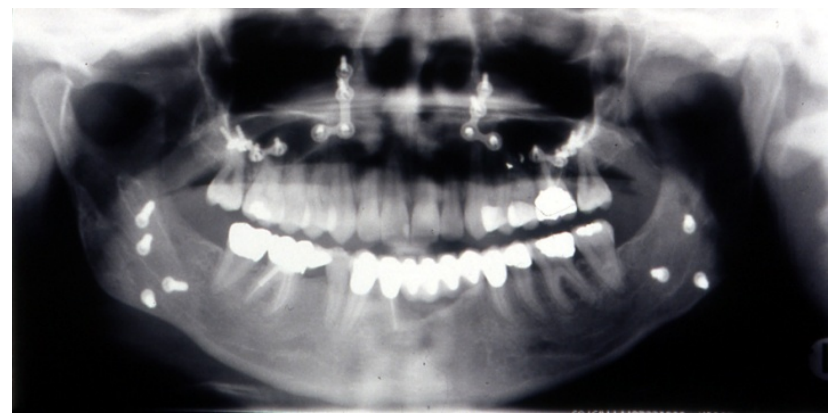

Figure 11. Superposition of the cephalograms pre- and posttreatment.

Superimposition of the cephalograms in S-N-S show the skeletal and soft tissue changes in the sagittal and vertical dimension (Fig. 11). Is the position of the pogonion in the sagittal plane checked one can see that the distance between post treatment and pre treatment is larger than the surgical advancement of the mandible. This is due to the autorotation of the mandible after impaction of the maxilla which is partially responsible for the correction of the distal occlusion $[21,22,23,26,32]$. The changes in the posterior teeth in the vertical and partially in the in the sagittal dimension are also effects of the impaction of the maxilla and autorotation of the mandible. The panoramic radiograph (Fig 12) after insertion of prosthodintics show the material of the osteogenesis and the replacement of teeth in the anterior and posterior segment.

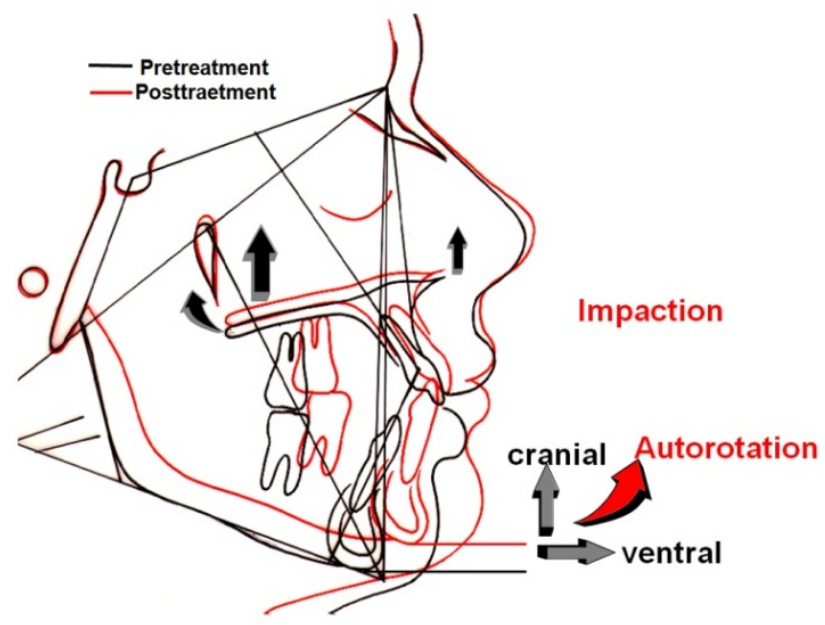

Figure 12. Orthopantomogramm after treatment

In accordance with the results of Radney\&Jacobs [ 42 ] concerning cranial displacement of the pronasal point, follow up studies of Collins and Epker ${ }^{14}$ and Rosen ${ }^{43}$ concerning raising of the tip of the nose with impaction of the maxilla these effects could also be seen in the presented case. These results were also confirmed independently by several authors [ 4-7, 13, 17, 25, 27, 28, 30, 33-42], and especially by De Assis et al. [ 18 ] and Lee et al.[ 33 ].

The patient is clinically symptomless, joint- and chewing function as well as mobility of the mandible are unlimited.

The Patient was satisfied with the accomplished functional and esthetic situation after treatment.

\section{Conclusions}

By means of the systematic treatment approach presented, class II deformities with a skeletal open bite and long lower face can be treated with predictable success and without esthetic compromises. The treatment result shows that it is necessary to adapt the dentoalveolar Sitation to the skeletal dysgnathia to end with a satisfactory result with respect to function, esthetics and stability. It can be concluded that it is only possible to reach the preset treatment goals with an exact diagnosis and knowledge of the necessary orthodontic preparation in combination with the surgical procedure.

\section{REFERENCES}

[1] Akay, M.C., Aras A. \& Günbay T., et al.: Enhanced Effect 
of Combined Treatment with Corticotomy and Skeletal Anchorage in Open-bite Correction. J Oral Maxillofac Surg, 2010, 67: 563-569

[2] Aziz, S.R.. Simon P. Hullihen and the Origin of Orthognathic Surgery. Journal of Oral and Maxillofacial Surgery, 2004, 62: 1303-1307

[3] Baek, S.H.; Ahn, H.W.; Kwon, Y.H. \& Choi, J.Y.: Surgery First Approach in Skeletal Class III Malocclusion Treated with 2-Jaw Surgery: Evaluation of Surgical Movement and Postoperative Orthodontic Treatment. Journal of Craniofacial Surgery, 2010, .21: 332-338

[4] Bell WH, Proffit HR, White RP. Surgical correction of facial deformities. Saunder Verlag, Baltimor, 1980.

[5] Bell WH, Schdeman GB. Correction of vertical maxillary deficiency: Stability and soft tissue changes. J Oral surg 1981; 39: 666-670.

[6] Bell HW, Jacobs JD. Simultaneous repositioning of the maxilla, mandible, and chin. Treatment planning and analysis of the soft tissues. Am J Orthod 1986; 91: 28-50.

[7] Buddgaard M, Melsen B, Terp S. Changes during and following total maxillary osteotomy (Le Fort I Procedure): a cephalometric study. Eur J Orthod 1986; 8: 21-29.

[8] Burstone GJ. The integumental profile. Am J Orthod 1958; 44: $1-25$.

[9] Burstone GJ. Lip posture and its significance in treatment planning. Am J Orthod 1967; 53: 262-84.

[10] Calangna L, Silverman S, Garfinkel L. Influence of neuromuscular conditioning on centric relation registrations. J Prosthet Dent 1973; 30: 598-604.

[11] Celenza, F V. The centric position. replacement and character. J Prosthet Dent 1973; 30: 591-598.

[12] Carlson DS, Ellis E, Dechow PC. Adptation of the suprahyoid muscle complex to mandibular advancement surgery. Am J Orthod 1987; 92: 134-143.

[13] Coh-Stock C. Die chirurgische immediate Regulierung der Kiefer, chirurgische Behandlung der Prognathie. Dtsch Vjschr Zahnheik 1921; 37: 320-331.

[14] Collins P, Epker BN. The alar basse Cinch: A technique for prevention of alar base flaring secondary to maxillary surgery. Oral Surg 1982; 53: 549-554.

[15] Dal Pont G. L'osteotomia retromolare per la correzione della progenia, Minerva chir.,1959; 18: 1138-1141.

[16] Dal Pont G. Die retromolare Osteotomie zur Korrektur der Progenie, der Retrogenie und des Mordex apertus. Öst Z Stoma 1961; 58: 8-10.

[17] Dann JJ, Fonseca RJ, Bell WH. Soft tissue changes associated with total maxillary advancement: a preliminary study. J Oral Surg 1976; 34: 19-23.

[18] De Assis EA, Starck WJ, Epker B. Cephalometric analysis of profile nasal esthetics. Part III. Postoperativ changes after isolated superior repositioning. Int J Adult Orthod Orthognath 1996; 11: 279-288

[19] Ellis $\mathrm{E}$; Hinton $\mathrm{Rj}$. Histologic examination of the temporomandibular joint after mandibular advancement with and without rigid fixation: An experimental investigation in adult Maccaca mulatta. J Oral Maxillofac Syrg 1991; 49: 1316.

[20] Ellis E. Condylar Positioning Devices for Orthodontic Surgery: Are They Necessary. J Oral Maxillofac Syrg 1994; 52: 536-552.

[21] Epker BN, Fish LC. Surgical-orthodontic correction of open-bite deformity. Am J Orthod 1977; 71: 278-299.

[22] Epker BN, Fish LC. Surgical superior repositioning of the maxilla: What to do with the mandibile?. Am j Orthod 1980; 78: 164-191.

[23] Epker B. Esthetic maxillofacial surgery. Lea und Febiger Verlag, Philadelphia, 1994.

[24] Ermel, T., Hoffmann J.\& Alfter G., et al.: Long-term stability of treatment results after upper jaw segmented osteotomy according to Schuchardt for correction of anterior open bite. J Orofac Orthop 1999, 60: 36-245

[25] Freihofer HPM. Changes in nasal Profile after maxillary advancement in cleft and non-cleft patients. J Maxillofac Surg 1977; 5: 20-27.

[26] Friede H, Kahnberg K-E, Adell R, Riedell A. Accuracy of cephalometric prediction in orthognatic surgery. J Oral Maxillofac Surg 1987; 45: 754-760.

[27] Hogeman KE, Sarnäs KV, Willmar K. One-stage surgical and dental-orthopedic correction of bimaxillary and craniofacial dysostosis. In: Fortschr Kiefer Gesichtschr, Bd 18: 39-49, Thieme Verlag, Stuttgart, 1974.

[28] Hui E, Hägg EUO, Tidman H. Soft tissue changes following maxillary osteotomies in cleft lip and palate and non-cleft Patients. J Craniomaxillofac Surg 1994; 22: 182-186.

[29] Hullihen, S.R. Case of elongationof the under jaw and distorsion of the face and neck, caused by a burn. Dent.Cosmos, Philadelphia. 42: 287-293, 1900. (Reprintdes Artikels von 1849).

[30] Jensen AC, Sinclair PM, Wolford LM. Soft tissue changes associated with double jaw surgery. Am J Orthod Dentofac Orthop 1992; 101: 266-275.

[31] Kondo E. \& Aoba, T.J. (2000). Nonsurgical and Nonextraction Treatment of Skeletal Class III Open Bite: Its Long-Term Stability. American Journal of Orthodontics and Dentofacial Orthopedics, 2000, 117: 267-287

[32] Kondo E. \& Arai, S.: Nonsurgical and Nonextraction Treatment of a Skeletal Class III Adult Patient with Severe Prognathic Mandible. World Journal of Orthodontics, 2005, .6: 233-247

[33] Lee DY, Bailey LJ, Proffit WR. Soft tissue changes after superior repositioning of the Maxilla with Le Fort I osteotomy: 5-years follow-up. Int J Adult Orthod Orthognath 1996: 11: 301-311.

[34] Legan HL, Burstone GJ. Soft tissue cephalometric analysis for orthognathic surgery. J Oral Surg 1980; 38: 744-51.

[35] Lindorf HH. Funktionsstabile Tandem-Verschraubung der sagittalen Ramusosteotomie -Operationsthenik, neue Instrumente und Erfahrungen. Dtsch Z Mund Kiefer Gesichtschir 1984; 8: 367-373. 
[36] Lindorf HH. Sagittal ramus osteotomy with tandem screw fixation -technique and results. J. Maxillofac Surg 1986; 14: 311-316.

[37] Liou, E.J.; Chen, P.H.; Wang, Y.C.; Yu, C.C.; Huang, C.S. \& Chen, Y.R.: Surgery-First Accelerated Orthognathic Surgery: Orthodontic Guidelines and Setup For Model Surgery, Journal of Oral and Maxillofacial Surgery, 2011, 69: 771-780

[38] O’Brien, K.; Wright, J.; Conboy, F.; Appelbe, P.; Bearn, D.; Caldwell, S.; Harrison, J.; Hussain,J.; Lewis, D.; Littlewood, S.; Mandall, N.; Morris, T.; Murray, A.; Oskouei, M.; Rudge, S.; Sandler, J.; Thiruvenkatachari, B.; Walsh, T. \& Turbill, E.: Prospective, Multi-Center Study of the Effectiveness of Orthodontic/OrthognathicSurgery Care in the United Kingdom, American Journal of Orthodontics and Dentofacial Orthopedics, 2009, 135: 709-714

[39] Obwegeser H., Trauner R. Zur Operationstechnik bei der Progenie und anderen Unterkieferanomalien. Dtsch Zahn Mund Kieferheilk 1955; 23: 1-17.

[40] Obwegeser $H$. The surgical correction of mandibular prognathism and retrognathia with consideration of genioplasty. J Oral Surg 1957; 10: 687-692.

[41] Obwegeser H. The indication for surgical correction of mandibular deformity by sagittal splitting technique. $\mathrm{Br} \mathrm{J}$ Surg 1963; 1: 157-166.

[42] Radney LJ, Jacobs JD. Soft tissue changes associated with surgical total maxillary intrusion. Am J Orthodont 1981; 80: 191-212.

[43] Rekow ED, Speidel TM, Koenig RA. Location of the mandibular center of Autorotation in maxillary impaction surgery. Am J Orthod Dentofac Orthop 1993; 103: 530-536.

[44] Rosen HM. Lip-nasal esthetics follwing Le Fort I Osteotomy. Plast Reconstr Surg 1988; 81: 171-182.
[45] Schuchardt K. Formen des offenen Bisses und ihre operativen Behandlungsmöglichkeiten. Fortsch Kiefer Gesichtschir. Bd 1, Thieme Verlag, Stuttgart, 1955.

[46] Stansbury CD, Evans CA, Miloro M, BeGole EA, Morris DE.: Stability of open bite correction with sagittal split osteotomy and closing rotation of the mandible.J Oral Maxillofac Surg 2010;68:149-159.

[47] Togawa R, Iino S, Miyawaki S.: Skeletal Class III and open bite treated with bilateral sagittal split osteotomy and molar intrusion using titanium screws. Angle Orthod 2010, 80: 1176-184.

[48] Watted N, Bill J. Untergesichtsverlängerung bei der Klasse-II-Dysgnathien: Neues von der kieferorthopädisch-kieferchirurgischen Therapie.Ästhe Zahnmed 1999; 4: 1992-300.

[49] Watted N, Witt E, Bill J. Therapy Conzept for the combined orthodontic-surgical Treatment of Angle Class II Deformities with Short-face Syndrome: New Aspects for surgical Lengthining of the Lower Face. Clin Orthod research, 2000; 3:78-93

[50] Watted N, Bill J, Witt E, Reuther J. Lengthening of the lower face Angle class II patients with skelettaly deep bite (short-face-syndrome) through combined orthodontic-surgical treatment. 75th Congress of the European Orthodontic Society Strasbuorg, France1999.

[51] Westermark AH, Bystedt H, von Konow L, Sällström KO. Nasolabial morphology after Le Fort I Osteotomies. Int J Oral Maxillofac Surg 1991; 20: 25-30.

[52] Williamsone EH, Evans DL, Barton WA, Williams BH. The effect of bite plane use on terminal hinge axis location, Angle Orthod. 1977; 47: 25-33.

[53] Williamsone EH, Caves SA, Edenfield RJ, Morse PK. Cephalometric analysis: comparisons between maximum intercuspation and centric relation, Am J Orthod 1978; 74 : 672-677. 